
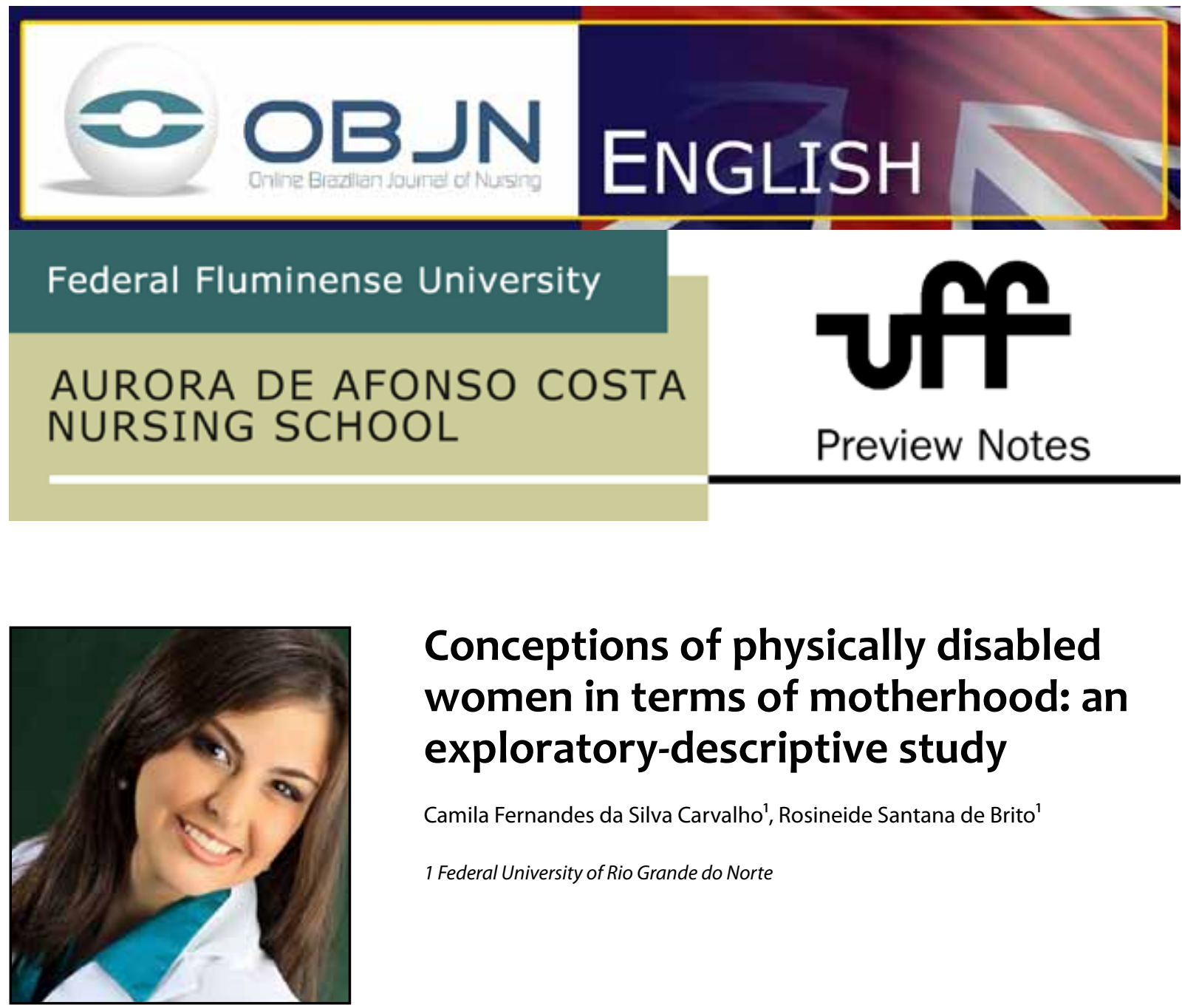

\title{
Conceptions of physically disabled women in terms of motherhood: an exploratory-descriptive study
}

\author{
Camila Fernandes da Silva Carvalho', Rosineide Santana de Brito ${ }^{1}$ \\ 1 Federal University of Rio Grande do Norte
}

\begin{abstract}
Problem: Women's daily experiences in terms of their disability and their influence on their lives, on their families and in the social environment, interfere with important decisions such as motherhood. Aim: To understand the conceptions of physically disabled women in terms of their ability to gestate, give birth or raise a child. Method: This is an exploratory and descriptive study in which a qualitative approach was used, carried out with twelve (12) physically disabled women registered in three non-governmental organizations in Natal, Rio Grande do Norte (RN), Brazil. Data collection occurred during the period from April to June 2014, by means of semi-structured interviews. A script consisting of socio-demographic questions and guiding question was used. The information obtained follows the precepts of Bardin's content analysis, and makes use of the thematic analysis technique. The principles of Symbolic Interactionism proposed by Blumer and correlated scientific literature was adopted as a theoretical and methodological framework.
\end{abstract}

Descriptors: Nursing; Reproductive Health; Maternal Health Services; Disabled Persons. 


\section{PROBLEM SITUATION AND ITS SIGNIFICANCE}

Physical disability is a limitation that affects individuals of different social classes, regardless of gender. Disabled people constitute $23.9 \%$ of the population and $56.6 \%$ of these people are female ${ }^{(1)}$. In this world, such women face discrimination, not only for their limitations, but also for their gender. In the eyes of society, the roles of wife, mother and caregiver are not achieved by disabled women because they are seen as being unable to relate sexually, and therefore produce children ${ }^{(2)}$. This fact is widely perceived in society given such women's physical and motor limitations, since this is a deficiency that most arouses the idea of incapacity in the population.

In contrast, when motherhood is desired, disabled women may find in this event a chance to prove that they are able to fulfil the social role played by non-disabled women, and confirm their feminine identity. For this, they need to make the effort, demonstrating that they are able to assume the role and overcome a stigma that is still present in current society, and that may influence their decision ${ }^{(2)}$.

Considering this situation, nursing is a profession that aims to promote health and plays a fundamental role in ensuring the rights of persons with disabilities as well as their need for assistance, in order to preserve their autonomy ${ }^{(3)}$. In this context, we include the sexual and reproductive health of physically disabled women. Thus, it becomes important to understand the conception that these women have in terms of motherhood, in the light of societal expectations and the social barriers faced.

With this understanding, we expect to effectively contribute to assisting disabled women who wish to become mothers.

\section{RESEARCH QUESTION}

What is the conception of physically disabled women in terms of their ability to gestate, give birth and raise a child?

\begin{abstract}
AIM
To understand the conception of physically disabled women in terms of their ability to gestate, give birth and raise a child.
\end{abstract}

\section{METHOD}

This is an exploratory and descriptive study in which a qualitative approach was used, performed in three non-governmental organizations in Natal (RN), Brazil. The twelve physically disabled women who were interviewed met the following inclusion criteria: to be female with a physical disability, to be aged between 18 and 49 years, and to affirm the existence of limiting characteristics from early childhood (from birth to three years). Women who had difficulty in communicating, had multiple disabilities and were infertile were excluded. It is noteworthy that this sample met the principle of data saturation, that is, the number of participants was considered adequate when the interviews did not provide new information.

Data collection occurred during the period April to June 2014, through unstructured interviews that included socio-demographic questions and a guiding question.

The treatment of the information obtained will follow the precepts of Bardin' content analysis, and will follow the thematic analysis technique. The data will be analyzed in the light of the principles of Blumer's interactionist theory, and will be discussed according to literature 
findings on health care aimed at supporting disabled women in the context of reproduction. The project was approved by the Research Ethics Committee, Federal University of Rio Grande do Norte in accordance with the CAAE Number 27442814.7.0000.5537.

\section{REFERENCES}

1. Instituto Brasileiro de Geografia e Estatística (Brasil). Censo Demográfico 2010: Características gerais da população, religião e pessoas com deficiência. Rio de Janeiro: IBGE; 2012.

2. Nicolau SM, Schraiber LB, Ayres JRCM. Mulheres com deficiência e sua dupla vulnerabilidade: contribuições para a construção da integralidade em saúde. Ciênc. saúde coletiva [internet]. 2013 [Cited 19 May 2013] 18(3). Avaliable from: http:// www.scielo.br/pdf/csc/v18n3/32.pdf.

3. Baptista RS, Vieira NFC, Ximenes LB, Pagliuca LMF. An analysis on the legislation for disabled people: descriptive-exploratory study. Online Braz J Nurs [Internet]. 2010 [Cited 29 Jul 2014] 9(1). Avaliable from: http://www.objnursing.uff.br/index.php/ nursing/article/view/j.1676-4285.2010.2762/616
All authors participated in the phases of this publication in one or more of the following steps, in According to the recommendations of the International Committee of Medical Journal Editors (ICMJE, 2013): (a) substantial involvement in the planning or preparation of the manuscript or in the collection, analysis or interpretation of data; (b) preparation of the manuscript or conducting critical revision of intellectual content; (c) approval of the versión submitted of this manuscript. All authors declare for the appropriate purposes that the responsibilities related to all aspects of the manuscript submitted to OBJN are yours. They ensure that issues related to the accuracy or integrity of any part of the article were properly investigated and resolved. Therefore, they exempt the OBJN of any participation whatsoever in any imbroglios concerning the content under consideration. All authors declare that they have no conflict of interest of financial or personal nature concerning this manuscript which may influence the writing and/or interpretation of the findings. This statement has been digitally signed by all authors as recommended by the ICMJE, whose model is available in http://www. objnursing.uff.br/normas/DUDE_eng_13-06-2013.pdf

Received: 08/13/2014

Revised: 08/21/2014

Approved: 08/25/2014 